WE examined the effect of the immunosuppressive agent, tacrolimus (FK506), on antigen-induced bronchial hyperreactivity to acetylcholine and leukocyte infiltration into the airways of ovalbumin-challenged guinea-pigs. Subcutaneous injection of $0.5 \mathrm{mg} / \mathrm{kg}$ of FK506, $1 \mathrm{~h}$ before and $5 \mathrm{~h}$ after intra-nasal antigen challenge prevented bronchial hyperreactivity to aerosolized acetylcholine, eosinophilia in bronchoalveolar lavage (BAL) fluid and bronchial tissue and the invasion of the bronchial wall by $\mathrm{CD4}^{+}$ T-lymphocytes. FK506 also suppressed ovalbumininduced increase in the number of leukocytes adhering to the pulmonary vascular endothelium and expressing $\alpha 4$-integrins. Inhibition by FK506 of antigen-induced bronchial hyperreactivity in sensitized guinea-pigs may thus relate to its ability to prevent the emergence of important inflammatory components of airway inflammation, such as eosinophil accumulation, as well as $\mathrm{CD}^{+}{ }^{+} \mathrm{T}$-lymphocyte infiltration into the bronchial tissue.

Key words: T-lymphocytes, Eosinophils, Immunohistochemistry, Immunosuppressive drugs, $\alpha 4$-integrins

\section{Prevention of antigen-induced bronchial hyperreactivity and airway inflammation in sensitized guinea-pigs by tacrolimus}

\author{
J. R. Lapa e Silva, ${ }^{1}$ C. Ruffié, ${ }^{2}$ J. Lefort, ${ }^{2}$
}

M-A. Nahori, ${ }^{2}$ B. B. Vargaftig ${ }^{2, C A}$ and M. Pretolani ${ }^{2}$

${ }^{1}$ Hospital Universitário Clementino Fraga Filho, Universidade Federal do Rio de Janeiro, Brazil;

${ }^{2}$ Unité de Pharmacologie Cellulaire, Unité Associée Institut Pasteur/INSERM U485, Paris, France

\footnotetext{
${ }^{\mathrm{CA}}$ Corresponding author

Tel: (+33) 145688682

Fax: (33) 145688703

Email: vargafti@pasteur.fr
}

\section{Introduction}

Despite the increasing knowledge regarding the pathogenesis of asthma, its prevalence, number of hospital admissions due to acute exacerbations, and its mortality increase continuously in most parts of the world. ${ }^{1}$ The complex cascade of inflammatory events that leads to chronic asthma, with the development of mucosal inflammation and bronchial hyperreactivity, becomes increasingly apparent. The importance of the association between T-lymphocytes, particularly of the $\mathrm{CD}^{+}$subset, and eosinophils in the pathogenesis of the disease is now well established. $^{2-11}$ However, some mechanisms involved in the inflammatory process are still open to doubts.

Using the model of sensitized and challenged guinea-pigs to dissect the mechanisms of allergic airway inflammation, ${ }^{12}$ we have shown that the development of bronchial hyperreactivity is chronologically associated with infiltration of $\mathrm{CD}^{+}$ T-lymphocytes and eosinophils in the bronchial wall. ${ }^{13,14}$ We also demonstrated that the mere presence of eosinophils in the bronchial mucosa is not necessarily translated into bronchial hyperreactivity. Activation of these cells by certain mediators, such as leukotriene $\mathrm{B}_{4}$, with the subsequent release of the cationic proteins, including major basic protein (MBP) and eosinophil peroxidase (EPO), is required for the development of marked bronchial hyperreactivity to methacholine. ${ }^{15}$
Mobilization of leukocytes into inflamed tissues requires the induction, on their surface, of adhesion molecules that are capable of interaction with their ligands expressed on endothelial cells. It has been shown that the expression of ICAM-1 on inflammatory cells is essential for the acquisition of bronchial hyperreacticity in primates. ${ }^{16}$ The family of the $\alpha 4$-integrins also plays a considerable role in allergic inflammation. ${ }^{17}$ We have indeed demonstrated that treatment of aerosol-sensitized guinea-pigs with an antibody directed against $\alpha 4$ - integrins prevents the development of bronchial hyperreactivity and the associated increase in the number of $\mathrm{CD}^{+} \mathrm{T}$-cells and eosinophils infiltrating the bronchial mucosa. ${ }^{18}$

Modulation of the bronchial inflammation by glucocorticosteroids is now the cornerstone for the treatment of asthma. ${ }^{1}$ Other classes of anti-inflammatory and immunosuppressive drugs, such as cyclosporin-A and tacrolimus (FK506), a macrolide with intense immunosuppressive activity resulting mostly from the inhibition of T-cell activation, ${ }^{19}$ have also been investigated in experimental systems. The further observations showing that FK506 prevents cytokine and mediator release from mast cells $^{20,21}$ suggested its potential usefulness in allergic inflammation.

In the present study, we used FK506 as a tool to evaluate inflammatory changes in the lungs following multiple intra-nasal (i.n.) antigen challenges in aerosol-sensitized animals. 


\section{Methods}

\section{Guinea-pig sensitization}

Male Hartley guinea-pigs (400-600 g, Charles River, St Aubin-les-Elbeuf, France) were immunized by aerosolized ovalbumin (Miles Naperville, IL, USA), at 1\% in sterile $0.9 \% \mathrm{NaCl}$ (saline) during $30 \mathrm{~min}$. The procedure was repeated $48 \mathrm{~h}$ later and the animals were exposed to antigen challenge 14 to 17 days after the first inhalation. ${ }^{18}$ The aerosol was delivered into a $36 \mathrm{~L}$ plexiglass chamber using a DeVilbiss ultrasonic nebulizer (Ultra-Neb 99, DeVilbiss Medical, Arcueil, France), which produced particles of a mass diameter averaging between 0.5 and $3 \mu \mathrm{m}$. The liquid output of the nebulizer was $0.6 \mathrm{ml} / \mathrm{min}$. The day of antigen provocation, guinea-pigs received an intraperitoneal (i.p.) injection of $4 \mathrm{mg} / \mathrm{kg}$ mepyramine maleate (Sigma, St Louis, MO) and, $15 \mathrm{~min}$ later, increasing concentrations of ovalbumin $(0.001 \%, 0.01 \%, 0.1 \%$, $0.5 \%$ and $1 \%$ ) were administered into the nostrils of each sensitized animal in a volume of $200 \mu 1$, every $15 \mathrm{~min}$.

Control guinea-pigs were sensitized as above and received i.n. sterile saline, in place of ovalbumin. The animals were used 6,24 or $72 \mathrm{~h}$ after challenge for cellular and MBP determinations in the BAL fluid and bronchial tissue and $72 \mathrm{~h}$ after challenge for measurement of bronchial hyperreactivity. Each experimental group was composed of six animals, unless otherwise stated.

\section{Treatments}

FK506 was administered subcutaneously (s.c.) to sensitized guinea-pigs, at the dose of $0.5 \mathrm{mg} / \mathrm{kg}, 1 \mathrm{~h}$ before and $5 \mathrm{~h}$ after antigen challenge. The drug was prepared according to instructions of the manufacturer: $10 \mathrm{mg}$ FK506 were dissolved in $1 \mathrm{ml}$ ethanol (Merck, Darmstadt, Germany) and $0.5 \mathrm{ml}$ of this solution was mixed with $0.1 \mathrm{ml}$ Tween 80 (Fluka Chemika, Buchs, Switzerland). The whole mixture was diluted with $4.4 \mathrm{ml}$ of sterile saline, to give a final concentration of $1 \mathrm{mg} / \mathrm{ml}$ FK506. Dilutions were performed in saline. Control animals received similar amounts of vehicle only, i.e. ethanol/Tween 80 injected by s.c. route.

\section{Assessment of bronchial hyperreactivity}

The day of the experiment, $72 \mathrm{~h}$ after the challenge, guinea-pigs were anaesthetized by an intra-peritoneal injection of $30 \mathrm{mg} / \mathrm{kg}$ sodium pentobarbital (ClinMidy Montpellier, France) and tracheae were cannulated.Animals were ventilated with a small respiratory pump (Biosciences, Sheeness, UK), at 60 strokes/min and $10 \mathrm{ml} / \mathrm{kg}$ body weight. The jugular vein was cannulated and spontaneous breathing was suppressed by the i.v. injection of $4 \mathrm{mg} / \mathrm{kg}$ of pancur- onium bromide (Organon Teknika, Fresnes, France). Airflow and transpulmonary pressure were measured and the lung resistance $\left(\mathrm{R}_{\mathrm{L}}\right)$ and dynamic compliance $\left(\mathrm{C}_{\text {dyn }}\right)$ were calculated using a computerized pulmonary monitoring system ( $\mu$ Med PMS, London, UK).

At least $1 \mathrm{~h}$ after surgery, bronchial reactivity was tested by the aerosol administration of increasing concentrations $(1,2,5,10,20$ and $50 \mathrm{mM})$ of acetylcholine (Sigma), at 15-min intervals between each. Six consecutive breaths of each dilution constituted the challenge dose. Acetycholine was inhaled using a DeVilbiss ultrasonic nebulizer (Ultra-Neb 99, DeVilbiss Medical, Arcueil, France), driven by compressed air and containing $0.5 \mathrm{ml}$ of the test solution. The mass diameter of the particles averaged between 0.5 and $3 \mu \mathrm{m}$. The liquid output of the nebulizer was $0.6 \mathrm{ml} / \mathrm{min}$.

Results were expressed as the provocative dose (PD) of acetylcholine, calculated from the doseresponse curve, required to increase the $\mathrm{R}_{\mathrm{L}}$ or to decrease the $\mathrm{C}_{\mathrm{dyn}}$ by $50 \mathrm{~cm} \mathrm{H}_{2} \mathrm{O} /($ litre/s) (PD50).

\section{Bronchoalveolar cell counts and differentiation}

In separate experiments, sensitized guinea-pigs challenged either with saline or ovalbumin and treated with FK506 or with its vehicle were anaesthetized as above and tracheae were cannulated. Bronchoalveolar cells were collected in five successive lavages using 10-ml aliquots of sterile saline at room temperature injected and recovered through a polyethylene tracheal cannula. The lavage fluid was stored on ice and total cell counts were performed using a Coulter Counter (model ZM, Coultronics, Margency, France). An aliquot of the suspension was then diluted to reach a final concentration of $1.5 \times 10^{5}$ cells $/ \mathrm{ml}$ and cytospin preparations were performed (Hettich Universal, Tuttingen, Germany). Differential cell counts were obtained by counting 300 cells after staining with Diff-Quik $^{\circledR}$ stain (American Scientific Products, Mc Gaw Park, IL, USA). The results are expressed as numbers of eosinophils/ml BAL fluid. Aliquots of $1 \mathrm{ml}$ of the remaining lavage fluid were centrifuged at $200 \mathrm{~g}$ for $15 \mathrm{~min}$ at $4^{\circ} \mathrm{C}$ and the supernatant was collected and stored at $-20^{\circ} \mathrm{C}$ until the determination of MBP, as described below.

\section{MBP determination by ELISA}

Eosinophil MBP (a gift from Dr M.K. Church, Southampton General Hospital, Southampton, UK) was purified, reduced, alkylated and dialysed, according to a modification of the procedure of Gleich et $a l .^{22}$

For the determination of MBP levels in the supernatants of BAL fluid, the samples were alkylated and reduced before the assay to avoid polymerization of the MBP molecule and ELISA was performed using the mouse anti-guinea-pig mAbs 8A12 and 8D12 (kindly 
provided by Drs G. Sturton and M. Fitzgerald, Bayer plc, Stoke Court, Slough, UK), as previously described. ${ }^{15,23,24}$ The lower detection limit of the assay was approximately $10 \mathrm{ng} \mathrm{MBP} / \mathrm{ml}$ sample.

\section{Immunohistochemistry}

After the BAL collection was performed as described above, guinea-pigs were exsanguinated via the abdominal aorta and the contents of the thoracic cavity resected en bloc. The lungs were inflated via the trachea with $3 \mathrm{ml}$ Histocon (Polysciences, Warrington, PA, USA), the lobes dissected and mounted over cork disks, covered by optimum cutting temperature compound $(\mathrm{BDH}$, Poole, UK) and snap frozen in isopentane (Prolabo, Paris, France) cooled by liquid nitrogen. The frozen blocks were kept at$80^{\circ} \mathrm{C}$ prior to use. Sections alongside the main intrapulmonary bronchus were cut in a cryostat kept at $-21^{\circ} \mathrm{C}$ and collected on glass slides previously coated with poly-l-lysine (Sigma), fixed in chloroform-acetone $\mathrm{v} / \mathrm{v}$ (Merck) for $10 \mathrm{~min}$, wrapped in a plastic film and kept at $-20^{\circ} \mathrm{C}$ prior to use. Representative sections of each block were also stained with haematoxylineosin (Rhône-Poulenc, Viliers-Saint Paul, France) for conventional histology.

Consecutive sections of each block were stained with the following monoclonal antibodies, as described: ${ }^{14}$ CT5 = mouse anti-guinea-pig T- lymphocytes, staining also macrophages and some B cells (provided by Dr R. Scheper, Free University, Amsterdam, The Netherlands); ${ }^{25}$ H155 = rat anti-guinea- pig CD4, recognizing helper T-lymphocytes (a gift from Drs $\mathrm{H}$ Schäfer and R. Burger, Robert-Koch Institute, Berlin, Germany); ${ }^{26}$ CT6 = mouse anti-guinea-pig CD8, recognizing suppressor/cytotoxic T cells (provided by Dr R. Scheper, Free University, Amsterdam, The Netherlands) ${ }^{25} \mathrm{HP} 1 / 2=$ mouse anti-human $\alpha 4$ - integrins ${ }^{27}$ (a gift from Dr R. R. Lobb, Biogen, Cambridge, USA), which cross-reacts with guinea-pig. ${ }^{28}$ For the murine antibodies (HP1/2, CT5 and CT6), alkaline phosphatase-anti-alkaline phosphatase (APAAP) staining procedure was performed using rabbit immunoglobulin (Ig) to mouse Ig (Z259, Dakopatts a/s, Copenhagen, Denmark) and mouse APAAP (D651, Dakopatts), followed by incubation with the substrates Fast Red TR (Sigma) and naphtol AS MX phosphate (Sigma), and light haematoxylin counterstaining. For the rat antibodies, APAAP staining was also performed, using rabbit Ig to rat Ig (D455, Dakopats), followed by rat APAAP (D488, Dakopatts) and similar development. Cyanide-resistant EPO activity, employing potassium cyanide (Merck), diaminobenzidine and hydrogen peroxide (Merck), was used to stain the eosinophils. ${ }^{14,29}$

At least two sections stained with each antibody or EPO technique, were coded and read in a 'blind' fashion. Positive cells were enumerated in the bron- chial wall in two compartments, submucosa (between the basal lamina and the smooth muscle), and adventitia (between the smooth muscle and the cartilage), and in the vessels (cells adhered to the endothelium and infiltrating the perivascular compartment), by means of an eyepiece graticule comprising 100 squares of known area. The area of the compartments and the number of positive cells were determined on each microscope field, and at least 10 fields were analysed. The results of each stained slide were expressed as the number of positive cells per unit area $\left(6.25 \times 10^{4} \mu \mathrm{m}^{2}\right.$, the total area of the graticule). Results were calculated per monoclonal antibody for each experimental group.

\section{Statistical analysis}

Results are expressed as mean \pm SEM of the indicated number of experiments. One- way ANOVA was used to determine significance among the groups. If a significant variance was found, an unpaired Student's $t$-test was used to assess comparability between means. A value of $P=0.05$ was considered significant.

\section{Results}

\section{Effect of FK506 on antigen-induced bronchial hyperreactivity in sensitized guinea- pigs}

In confirmation to our previous data, ${ }^{24}$ no changes in the intensity of bronchial responsiveness to acetylcholine were observed when saline-and ovalbuminchallenged animals were used 6 or $24 \mathrm{~h}$ after the challenge (data not shown).

When compared with saline-challenged animals, antigen-challenged vehicle- injected guinea-pigs showed airway hyperreactivity to inhaled acetylcholine at $72 \mathrm{~h}$, which was expressed by a decrease in PD50 values for both $\mathrm{R}_{\mathrm{L}}$ and $\mathrm{C}_{\mathrm{dyn}}$ (Fig. 1). Bronchial hyperreactivity to acetylcholine at $72 \mathrm{~h}$ was suppressed by thes.c. treatment of the animals with $0.5 \mathrm{mg} / \mathrm{kg}$ FK506, $1 \mathrm{~h}$ before and $5 \mathrm{~h}$ after the challenge (Fig. 1).

\section{Effect of FK506 on antigen-induced eosinophil accumulation and MBP release in the BAL fluid of sensitized guinea-pigs}

Ovalbumin inhalation by sensitized vehicle-treated guinea-pigs was followed by an increase in the number of eosinophils in the BAL fluid, which started at $6 \mathrm{~h}$ and reached a plateau at 24 and $72 \mathrm{~h}$ (Fig. 2A). Treatment of the animals with $0.5 \mathrm{mg} / \mathrm{kg}$ FK506, injected s.c. $1 \mathrm{~h}$ before and $5 \mathrm{~h}$ after the challenge, decreased markedly eosinophil accumulation in the BAL fluid at 24 and $72 \mathrm{~h}$, without affecting significantly that observed at $6 \mathrm{~h}$ (Fig. 2A). 


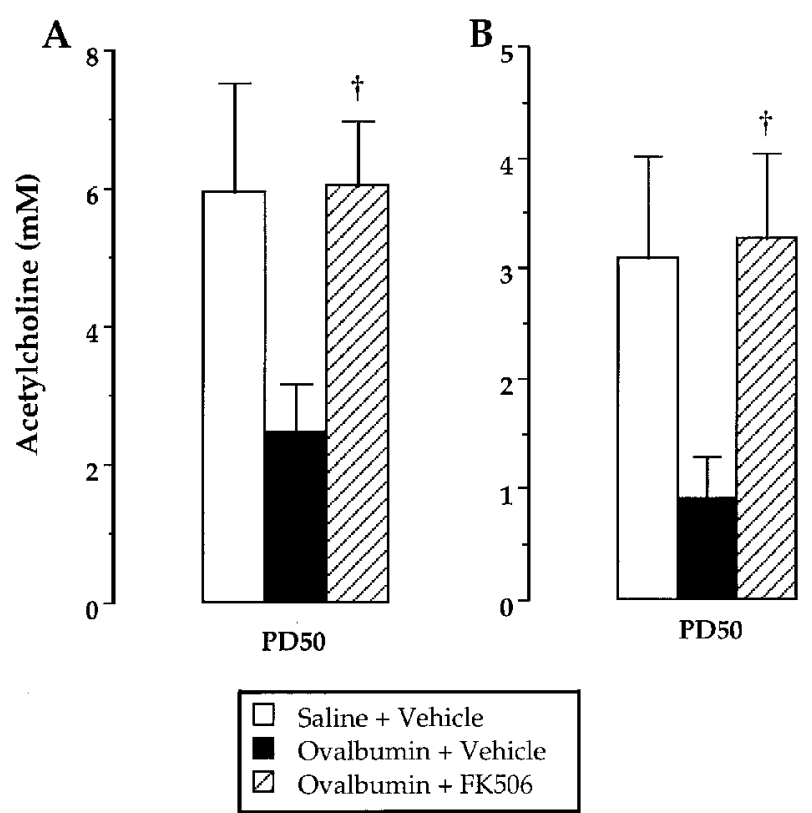

FIG. 1. Effect of FK506 on antigen-induced bronchial hyperreactivity to inhaled acetylcholine in sensitized guinea-pigs. Bronchial reactivity to inhaled acetylcholine (1-50 $\mathrm{mM}$ ) was evaluated in saline- and ovalbumin-challenged guinea-pigs, treated s.c. with $0.5 \mathrm{mg} / \mathrm{kg}$ FK506 or with its vehicle, $1 \mathrm{~h}$ before and $5 \mathrm{~h}$ after the challenge, and used $72 \mathrm{~h}$ thereafter. Results are expressed as provocative dose (PD) of acetylcholine, calculated from the dose-response curve, required to increase the $R_{L}$ (panel $A$ ) or to decrease the $C_{d y n}$ (panel $B$ ) by $50 \mathrm{~cm} \mathrm{H} \mathrm{H}_{2} \mathrm{O} /\left(\right.$ litre/s) (PD50). The baseline $\mathrm{R}_{\mathrm{L}}$ were of $155.7 \pm$ 9.6, $188.3 \pm 20.6$ and $171.2 \pm 10.5 \mathrm{~cm} \mathrm{H}_{2} \mathrm{O} /($ litre/s) , and that $\mathrm{C}_{\text {dyn }}$ were of $0.68 \pm 0.05,0.54 \pm 0.08$ and $0.72 \pm 0.06 \mathrm{~cm} \mathrm{H}_{2} \mathrm{O} /$ (litre/s), for saline- and ovalbumin-challenged vehicle- or FK506-treated guinea-pigs, respectively (differences not statistically significant). Data are means \pm SEM of 7-9 experiments. $\dagger P<0.05$, compared with ovalbumin-challenged vehicle-treated guinea-pigs.
Ovalbumin-challenged vehicle-treated guinea-pigs showed a rise in their BAL concentrations of MBP at 24 and $72 \mathrm{~h}$, but not at $6 \mathrm{~h}$ (Fig. 2B). FK506 significantly inhibited MBP production at $24 \mathrm{~h}$ (Fig. 2B). A marked reduction in MBP release was also noted in FK506-treated animals used $72 \mathrm{~h}$ after the challenge, but the high degree of variability in the control group precluded the results from achieving statistical significance $(90.5 \%$ inhibition, $n=6, P>$ $0.2)$.

\section{Effect of FK506 on antigen-induced cellular infiltration in the bronchial mucosa of sensitized guinea-pigs}

Antigen challenge was also followed by augmented eosinophil numbers in the bronchial mucosa, which reached a similar intensity at 6 and $24 \mathrm{~h}$, to decline at $72 \mathrm{~h}$ (Fig. 3). Most of the positive cells were found in the bronchial submucosa rather than in the adventitia (Fig. 3). The s.c. treatment of the animals with FK506 decreased markedly eosinophil infiltration in the bronchial mucosa at all time points and in both compartments (Fig. 3).

T-lymphocyte recruitment into the bronchial wall following antigen challenge was also curtailed by FK506 (Fig. 4). Indeed, the substantial increase in the numbers of $\mathrm{CT}^{+}$cells both in the bronchial submucosa and in the adventitia which was observed at all time-points after ovalbumin challenge was reduced significantly by FK506 (Fig. 4).
A

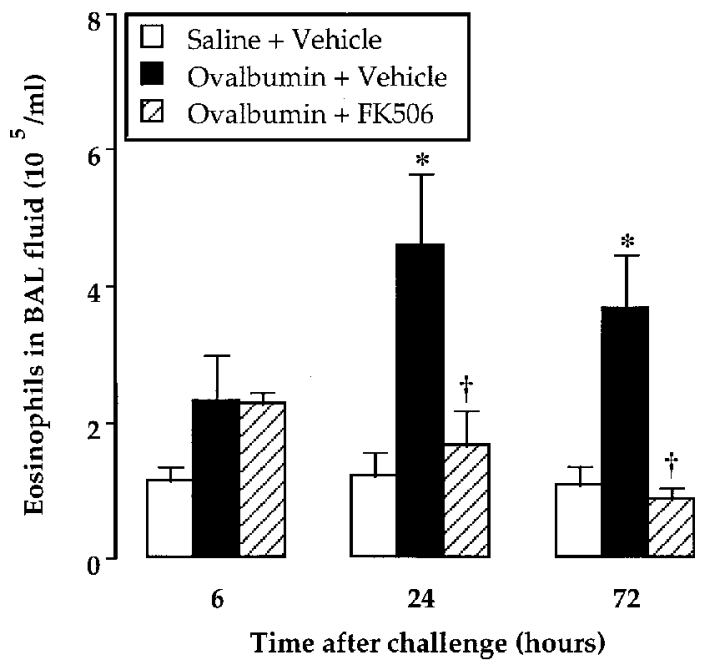

B

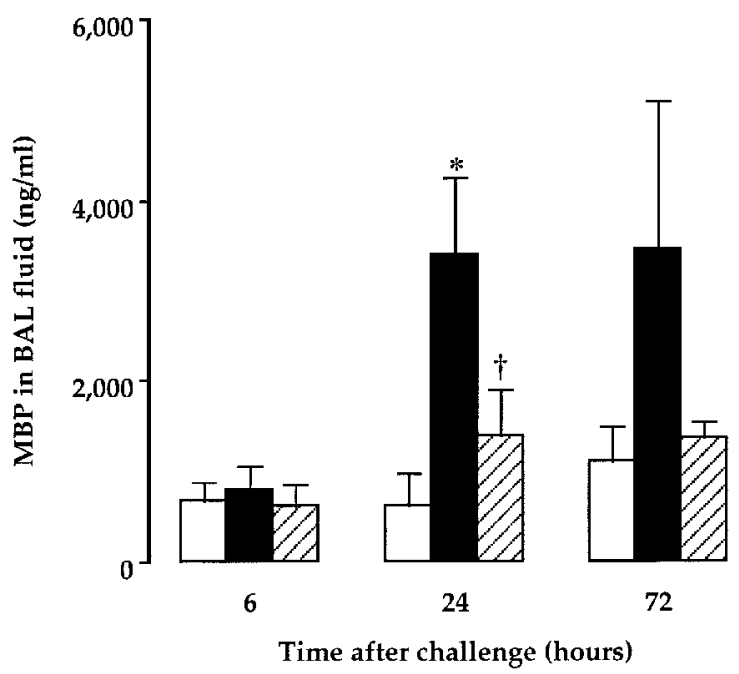

FIG. 2. Effect of FK506 on antigen-induced eosinophil accumulation (panel A) and MBP release (panel B) in the BAL fluid from sensitized guinea-pigs. Sensitized vehicle- or FK506 $(0.5 \mathrm{mg} / \mathrm{kg}$ )-treated animals were challenged with intra-nasal saline or ovalbumin and a BAL was performed 6, 24 or $72 \mathrm{~h}$ thereafter. Eosinophil numbers were determined on cytospin preparations stained with Diff-Quik ${ }^{\circledR}$ stain and MBP was measured in the cell-free supernatant of BAL fluid using a specific double sandwitch ELISA. Results are means \pm SEM of six experiments. ${ }^{*} P<0.05$, compared with saline-challenged vehicle-treated guinea-pigs. $\dagger P<0.05$, compared with ovalbumin-challenged vehicle-treated guinea-pigs. 
A

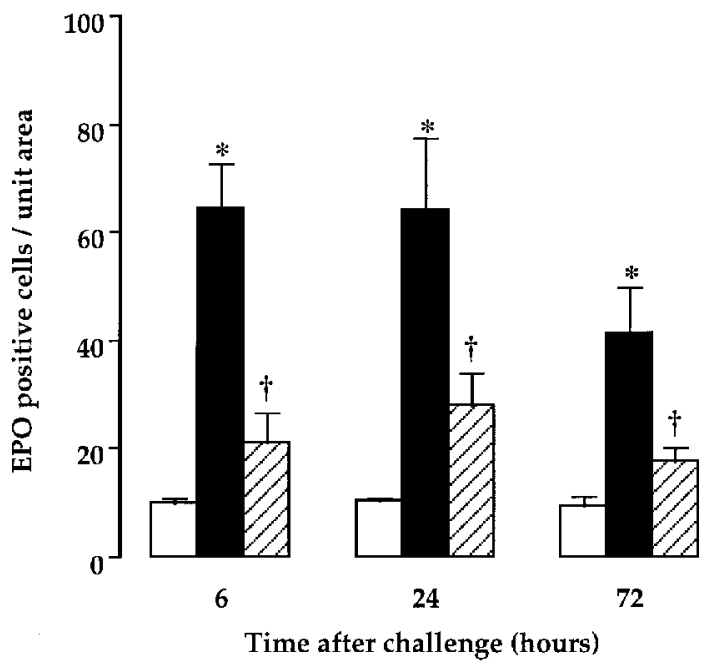

B

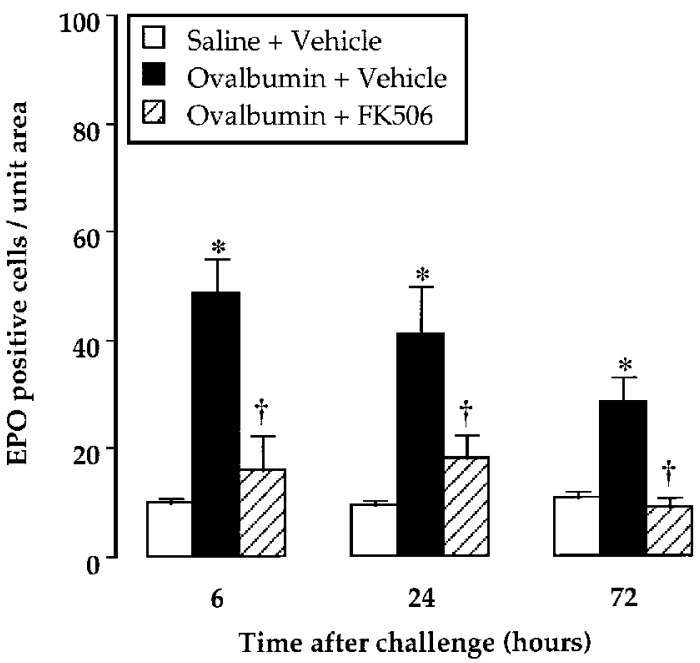

FIG. 3. Effect of FK506 on antigen-induced eosinophil infiltration in the bronchial mucosa from sensitized guinea-pigs. EPO cells in the bronchial submucosa (panel A) and in the adventitia (panel B) of sensitized guinea-pigs challenged with intranasal saline or ovalbumin and treateds.c. with $0.5 \mathrm{mg} / \mathrm{kg}$ of FK506, $1 \mathrm{~h}$ before and $5 \mathrm{~h}$ after antigen challenge. Animals were challenged and lungs removed 6,24 or $72 \mathrm{~h}$ thereafter. Results are means \pm SEM of six experiments. ${ }^{*} P<0.05$, compared with saline-challenged vehicle-treated guinea-pigs. $\dagger P<0.05$, compared with ovalbumin-challenged challenged vehicle-treated guinea-pigs.

An augmented number of $\mathrm{CD} 4^{+}$T-lymphocytes was also noted in the bronchial submucosa from sensitized vehicle-treated guinea-pigs after ovalbumin, particularly at 6 and $72 \mathrm{~h}$ (Fig. 5). FK506 was effective in reducing such infiltration down to the levels of saline-challenged vehicle-treated animals (Fig. 5). The numbers of $\mathrm{CD8}^{+} \mathrm{T}$ cells were not increased in antigen-challenged guinea-pigs and they were not modified after treatment with FK506 (data not shown).

A

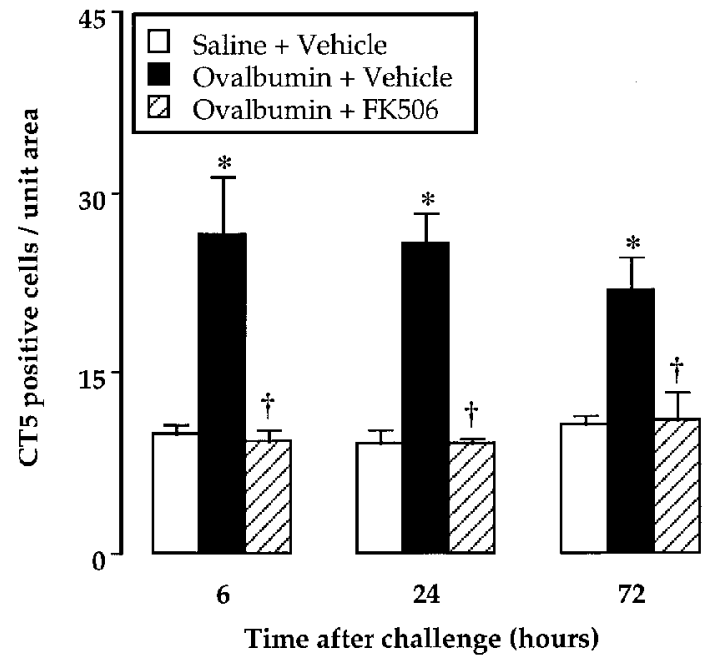

The presence of cells expressing $\alpha 4$-integrins, adhering to the vascular endothelium and infiltrating the perivascular compartment at the different time-points was then examined (Fig. 6). The number of $\alpha 4$-integrin positive cells was significantly increased $6 \mathrm{~h}$, but not 24 and $72 \mathrm{~h}$ after ovalbumin administration. At this time-point, FK506 reduced considerably the number of cells adhered to the endothelium or transmigrating into the tissues (Fig. 6).

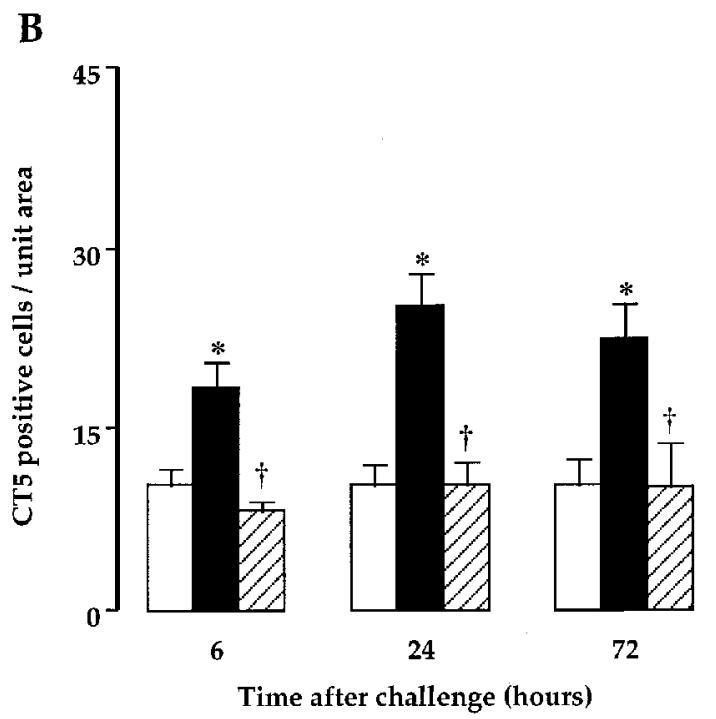

FIG. 4. Time-course of the effect of FK506 on antigen-induced T-lymphocyte accumulation in the bronchial submucosa (panel A) and in the adventitia (panel B) from sensitized guinea-pigs (CT5 staining and APAAP). Sensitized vehicle-or FK506 (0.5 mg/ $\mathrm{kg}$ )-treated animals were challenged with aerosolized saline or ovalbumin and lungs collected 6,24 or $72 \mathrm{~h}$ thereafter. Results are means \pm SEM of six experiments. ${ }^{*} P<0.05$, compared with saline-challenged vehicle-treated guinea-pigs. $t P<0.05$, compared with ovalbumin-challenged vehicle-treated guinea-pigs. 
A

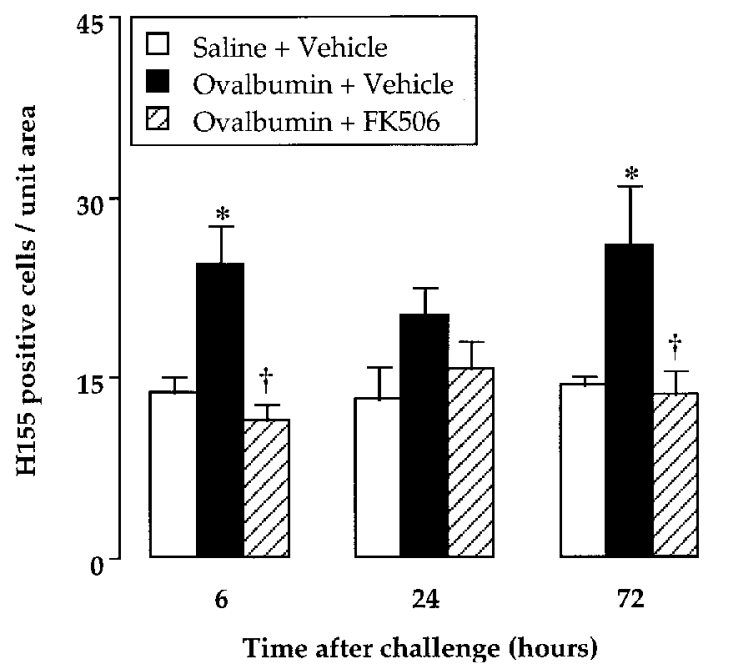

B

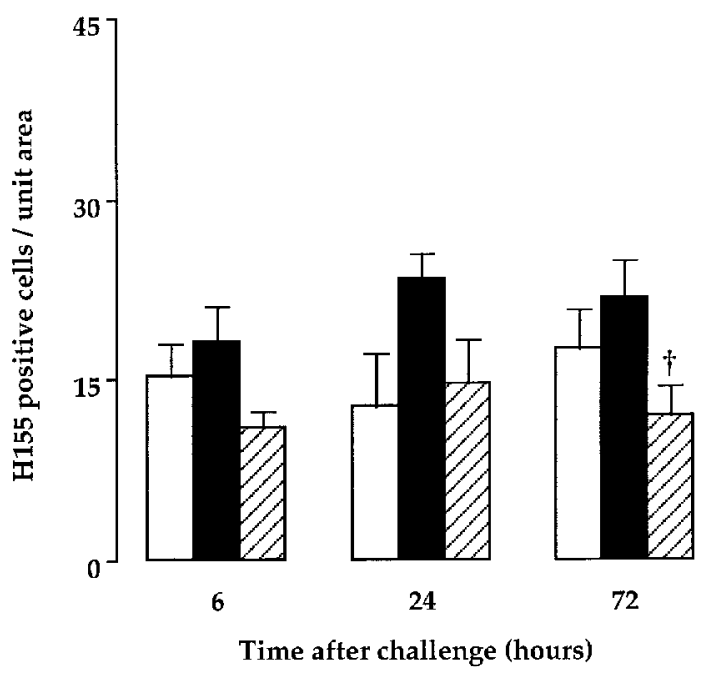

FIG. 5. Kinetics of the effect of FK506 on antigen-induced CD4 ${ }^{+}$T-lymphocyte infiltration into the bronchial mucosa of sensitized guinea-pigs (H155 staining and immunoperoxidase). Sensitized vehicle- or FK506 $(0.1 \mathrm{mg} / \mathrm{kg})$-treated animals were challenged with intra-nasal saline or ovalbumin and lungs collected 6, 24 or $72 \mathrm{~h}$ thereafter. Results are means \pm SEM of six experiments. ${ }^{*} P<0.05$, compared with saline-challenged vehicle-treated guinea-pigs. $\dagger P<0.05$, compared with ovalbumin-challenged vehicle-treated guinea-pigs.

\section{Discussion}

In the present study, we demonstrated that i.n. antigen challenge of sensitized guinea-pigs was followed by an early and transient increase in the number of cells adherent to pulmonary vascular endothelium and expressing $\alpha 4$-integrins. Although we were unable to

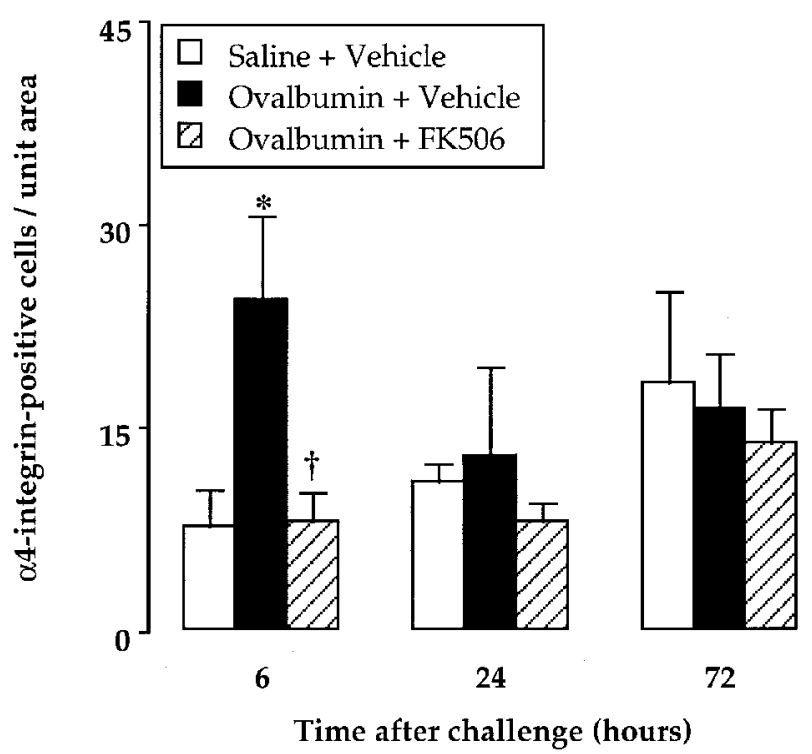

FIG. 6. Effect of FK506 on antigen-induced accumulation of $\alpha 4$ integrin positive cells in pulmonary endothelium and perivascular compartment from sensitized guinea-pigs (HP1/ 2 staining and APAAP). Sensitized vehicle- or FK506 $(0.5 \mathrm{mg} /$ $\mathrm{kg}$ )-treated animals were challenged with intra-nasal saline or ovalbumin and lungs were used at 6,24 or $72 \mathrm{~h}$. Results are means \pm SEM of six experiments. ${ }^{*} P<0.05$, compared with saline-challenged vehicle-treated guinea-pigs. $\dagger P<0.05$, compared with ovalbumin-challenged vehicle-treated guinea-pigs. distinguish these cells by lack of reagents for performing double staining, the possibility that they could be identified as T-lymphocytes and eosinophils appears likely. Indeed, $\alpha 4$-integrin expression was first accompanied (at $6 \mathrm{~h}$ ) and then followed (at 24 and $72 \mathrm{~h}$ ) by the infiltration of eosinophils and $\mathrm{CD}^{+} \mathrm{T}$-lymphocytes in the bronchial mucosa, two cell types which preferentially express $\alpha 4$-integrins on their surface. ${ }^{17}$ While the rise in the number of $\alpha 4$-integrin positive cells occurred as early as $6 \mathrm{~h}$ after the challenge and decreased thereafter, the invasion of the bronchial wall by eosinophils and T-cells remained at a plateau for at least $72 \mathrm{~h}$. Furthermore, no staining for $\alpha 4$-integrins was observed in the bronchial submucosa of antigenchallenged guinea-pigs at any time-point. Treatment of the sensitized guinea-pigs with FK506 prevented the adherence of $\alpha 4$-integrin positive cells to the vascular endothelium at $6 \mathrm{~h}$ and abrogated the subsequent infiltration of eosinophils and T-cells in the bronchial mucosa and BAL fluid. Whether the inhibition of leukocyte recruitment into the bronchial wall by FK506 is directly or indirectly related to a blockade of adhesion molecules expression is an attractive hypothesis which deserves further investigations.

The ability of FK506 to down-regulate T-cell activation has been demonstrated. ${ }^{19}$ This is translated into a decreased production of cytokines, including IL- 4 and TNF- $\alpha$, which directly facilitate the induction of adhesion molecules on endothelial cells. ${ }^{30,31}$ T-lymphocytes are also a source of other cytokines, such as IL-3, IL-5 and GM-CSF, which influence directly many aspects of eosinophil biology, including mobilization and activation, as well as the growth and differentiation from eosinophil precursors. ${ }^{32}$ Indeed, 
the total number of T-cells and of $\mathrm{CD}^{+}{ }^{+} \mathrm{T}$-lymphocytes in the bronchial mucosa of antigen-challenged FK506treated guinea-pigs was decreased down to the values of saline-exposed animals. One possible explanation for this phenomenon came from a recent study showing that FK506 augmented the apoptosis of CD3activated $\mathrm{CD}^{+}$and $\mathrm{CD}^{+}$T-lymphocytes in mice. ${ }^{33}$

In our model, ovalbumin inhalation was followed by the accumulation of activated eosinophils in the BAL fluid from sensitized guinea-pigs. Eosinophil activation was expressed by a rise in the levels of MBP in the cell-free supernatant of BAL fluid collected 24 and $72 \mathrm{~h}$ after antigen challenge. Both accumulation and MBP release were abolished by the administration of FK506. This probably derives from the effect of FK506 on T-lymphocytes and the release of IL-5, which leads to the blockage of eosinophil recruitment and accumulation in the lungs.

The T-cell dependency of allergic airway inflammation and bronchial hyperreactivity has been already investigated in different species, particularly the mouse. Thus, depletion of $\mathrm{CD}^{+}{ }^{+} \mathrm{T}-1 y m$ phocytes on one hand, ${ }^{34}$ and treatment with some immunosuppressors, including FK506, ${ }^{35}$ on the other hand, prevent BAL eosinophilia and the accompanying increase in bronchial sensitivity to spasmogens. Recently, it has been shown that the tacrolimus analogue cyclosporin-A can inhibit airway eosinophilic inflammation by suppressing IL-5 synthesis by T-cells. ${ }^{36}$

In conclusion, we provide evidence that, probably by acting on the early steps involved in leukocyte transmigration and infiltration into the bronchial lumen, the immunosuppressor tacrolimus abrogates most of the features of allergic airway inflammation in the guinea-pig, as well as their consequences on the alterations in lung function.

\section{References}

1. NHLBI/WHO report. Global initiative for asthma. Global strategy for asthma management and prevention. National Institutes of Health 1995; Publication number 95-3659.

2. Djukanovic R, Roche WR, Wilson JW, Beasley CRW, Twentyman OP, Howarth PH, Holgate ST. Mucosal inflammation in asthma. Am Rev Respir Dis 1990; 142: 434

3. Bousquet J, Chanez P, Lacoste JY, et al. Eosinophilic inflammation in asthma. N Engl J Med 1990; 323: 1033.

4. Corrigan CJ, Kay AB. T cells and eosinophils in the pathogenesis of asthma. Immunol Today 1992; 13: 501.

5. Holgate ST. Asthma: past, present and future. Eur Respir J 1993; 6: 1507.

6. Jeffery PK, Wardlaw AJ, Nelson FC, Collins JV, Kay AB. Bronchial biopsies in asthma. An ultrastructural, quantitative study and correlation with hyperreactivity. Am Rev Respir Dis 1989; 140: 1745

7. Azzawi M, Bradley B, Jeffery PK, et al. Identification of activated T lymphocytes and eosinophils in bronchial biopsies in stable atopic asthmatics. Am Rev Respir Dis 1990 142: 1407.

8. Corrigan CJ, Kay AB. CD4 T-lymphocyte activation in acute severe asthma. Relationship to disease severity and atopic status. Am Rev Respir Dis 1990; 141: 970.

9. Kay AB, Ying S, Varney V, et al. Messenger RNA expression of the cytokine gene cluster, interleukin-3 (IL-3), IL-4, IL-5, and granulocyte/macrophage colony-stimulating factor, in allergen-induced late-phase cutaneous reactions in atopic subjects. J Exp Med 1991; 173: 775.

10. Robinson DS, Hamid Q, Ying S, et al. Predominant Th2-like bronchoalveolar T-lymphocyte population in atopic asthma. N Engl J Med 1992; 326: 298.
11. Hamid Q, Azzawi M, Ying S, et al. Expression of mRNA for interleukin-5 in mucosal bronchial biopsies from asthma. J Clin Invest 1991; 87: 1541 .

12. Pretolani M, Vargaftig BB. From lung hypersensitivity to bronchial hyperreactivity. What can we learn from studies on animal models? Biochem Pharmacol 1993; 45: 791.

13. Pretolani M, Lefort J, Vargaftig BB. Active immunization induces lung hyperresponsiveness in the guinea pig. Pharmacological modulation and triggering role of the booster injection. Am Rev Respir Dis 1988; 138: 1572 .

14. Lapa e Silva JR, Bachelet CM, Pretolani M, Baker D, Scheper RJ, Vargaftig BB. Immunopathologic alterations in the bronchi of immunized guineapigs. Am J Respir Cell Mol Biol 1993; 9: 44.

15. Pretolani M, Ruffié C, Joseph D, et al. Role of eosinophil activation in the bronchial reactivity of allergic guinea-pigs. Am J Respir Crit Care Med 1994; 149: 1167.

16. Wegner C, Gundel RH, Reilly P, Haynes N, Letts LG, Rothlein R. Intercellular adhesion molecule-1 (ICAM-1) in the pathogenesis of asthma. Science 1990; 247: 456.

17. Lobb RR, Hemler ME. The pathophysiologic role of $\alpha 4$ integrins in vivo. J Clin Invest 1994; 94: 1722.

18. Pretolani M, Ruffié C, Lapa e Silva JR, Joseph D, Lobb RR, Vargaftig BB. Antibody to very-late activation antigen- 4 prevents antigen-induced bronchial hyperreactivity and cellular infiltration in the guinea-pig airways. J Exp Med 1994; 180: 795

19. Bishop DK, Li W. Cyclosporin and FK506 mediate differential effects on T-cell activation in vivo. J Immunol 1992; 148: 1049.

20. de Paulis R, Cirillo R, Ciccarelli A, de Crescenzo G, Oriente A, Marone G. Characterization of the anti-inflammatory effect of FK506 on human mast cells. J Immunol 1992; 147: 4278.

21. Hatfield SM, Rohem NW. Cyclosporin and FK506 inhibition of murine mast cell cytokine production. J Pharmacol Exp Ther 1992; 260: $680-688$.

22. Gleich GJ, Loegering DA, Macdonald JE. Identification of a major basic protein in guinea-pig eosinophil granules. J Exp Med 1973; 137: 1459.

23. HuntTC, Summers JA, Campos MG, et al. Monoclonal antibodies specific for guinea-pig major basic protein: their use in an ELISA, immunocytochemistry and flow cytometry. Clin Exp Allergy 1994; 23: 425.

24. Lefort J, Nahori M-A, Ruffié C, Vargaftig BB, Pretolani M. In vivo neutralization of eosinophil-derived major-basic protein inhibits antigeninduced bronchial hyperreactivity in sensitized guinea-pigs. J Clin Invest 1996; 97: 1117

25. Tan BTG, Ekellar F, Luirink J, Rimmelzaan G, de Jonge AJR, Scheper RJ. Production of monoclonal antibodies defining guinea-pig T-cell surface markers and a strain 13 Ia-like antigen: the value of immunohistological screening. Hybridoma 1985; 4 : 115.

26. Schäfer H, Burger R. Identification and functional characterization of guinea-pig CD4: antibody binding transduces a negative signal on T-cell activation. Immunology 1991; 72: 261.

27. Pulido R, Elices MJ, Campanero MR, et al. Functional evidence for three distinct and independently inhibitable adhesion activities mediated by the human integrin VLA-4. J Biol Chem 1991; 266: 10241.

28. Weg VB, Williams TJ, Lobb RR, Nourshargh S. A monoclonal antibody recognizing very late activation antigen- 4 inhibits eosinophil accumulation in vivo. J Exp Med 1993; 177: 561.

29. Zucker-Franklin D, Grusky G. The identification of eosinophil colonies in soft-agar cultures by differential staining for peroxidase. $J$ Histochem Cytochem 1976; 24: 1270.

30. Thornill MH, Haskard DO. IL-4 regulates endothelial cell activation by IL1 , tumor necrosis factor, or IFN- $\gamma$. J Immunol 1990; 145: 865.

31. Pober JS, Lapierre LA, Stolpen AH et al. Activation of cultured human endothelial cells by recombinant lymphotoxin: comparison with tumor necrosis factor and interleukin-1 species. J Immunol 1987; 138: 3319.

32. Lopez AF, Elliott MJ, Woodcock J, Vadas MA. GM-CSF, IL-3 and IL-5: crosscompetition on human haemopoietic cells. Immunol. Today 1992; 13: 495 .

33. Migita K, Eguchi K, Kawabe Y, Tsukada T, Mizokami A, Nagataki S. FK506 augments activation-induced programmed cell death of Tymphocytes in vivo. J Clin Invest 1995; 96: 727.

34. Nakajima H, Iwamoto I, Tomoe S et al. CD4 ${ }^{+}$T-lymphocytes and interleukin-5 mediate antigen-induced eosinophil infiltration into the mouse trachea. Am Rev Respir Dis 1992; 146: 374.

35. Nagai H, Yamaguchi S, Tanaka H, Inagaki N. Effect of some immunosuppressors on allergic bronchial inflammation and airway hyperresponsiveness in mice. Int Arch Allergy Immunol 1995; 108: 189.

36. Nakata A, Kaminura O, Mori A et al. Evidence that cyclosporin A and dexamethasone inhibit allergic airway eosinophillic inflammation via suppression of interleukin-5 synthesis by T cells. Br J Pharmacol 1998; 124: 1425 .

ACKNOWLEDGEMENTS. Dr J.R. Lapa e Silva was partially supported by CEPG/UFRJ, FUJB, and CNPq. Dr K. Murato (Fujisawa GmbH, Munich, Germany), is greatly acknowledged for the gift of FK506.

\section{Received 4 November 1998;} accepted 13 November 1998 


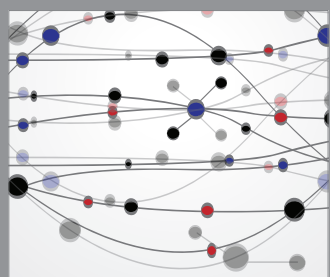

The Scientific World Journal
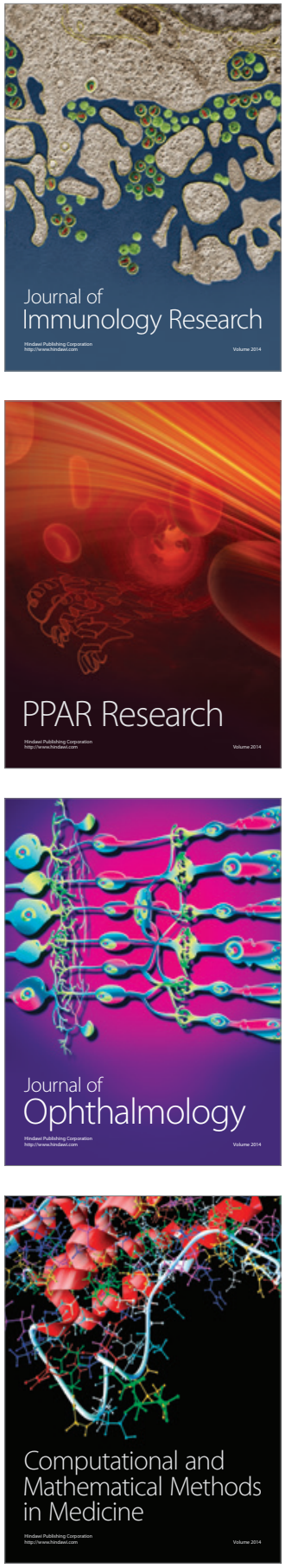

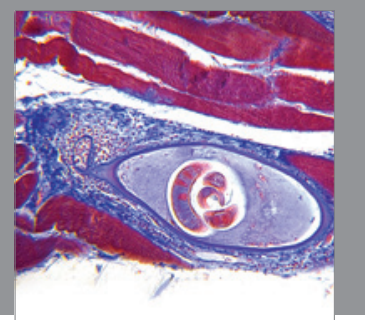

Gastroenterology

Research and Practice
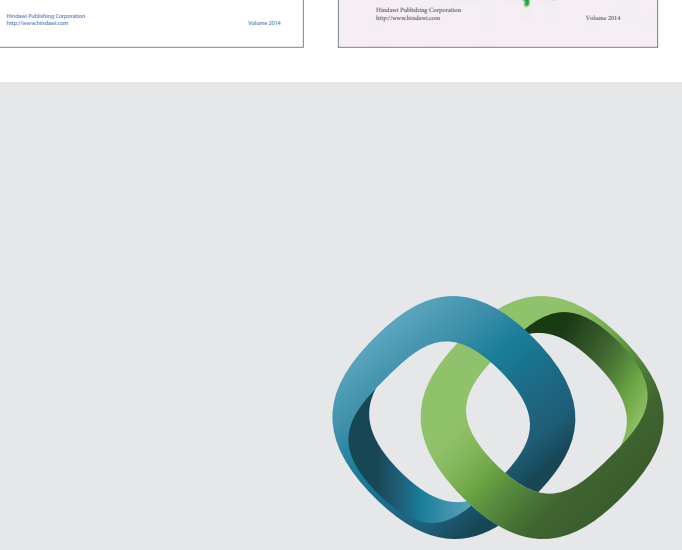

\section{Hindawi}

Submit your manuscripts at

http://www.hindawi.com
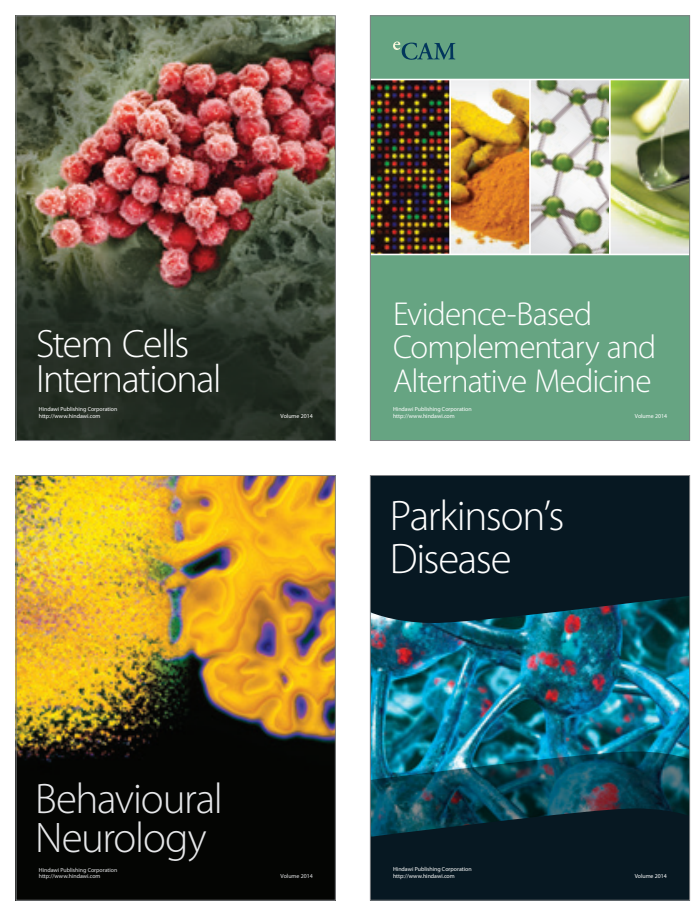

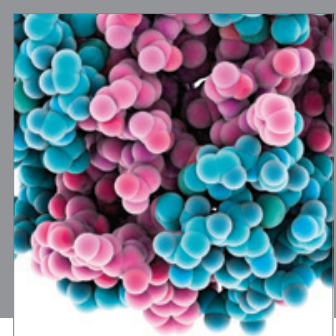

Journal of
Diabetes Research

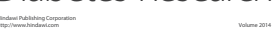

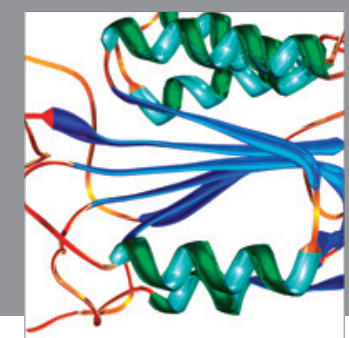

Disease Markers
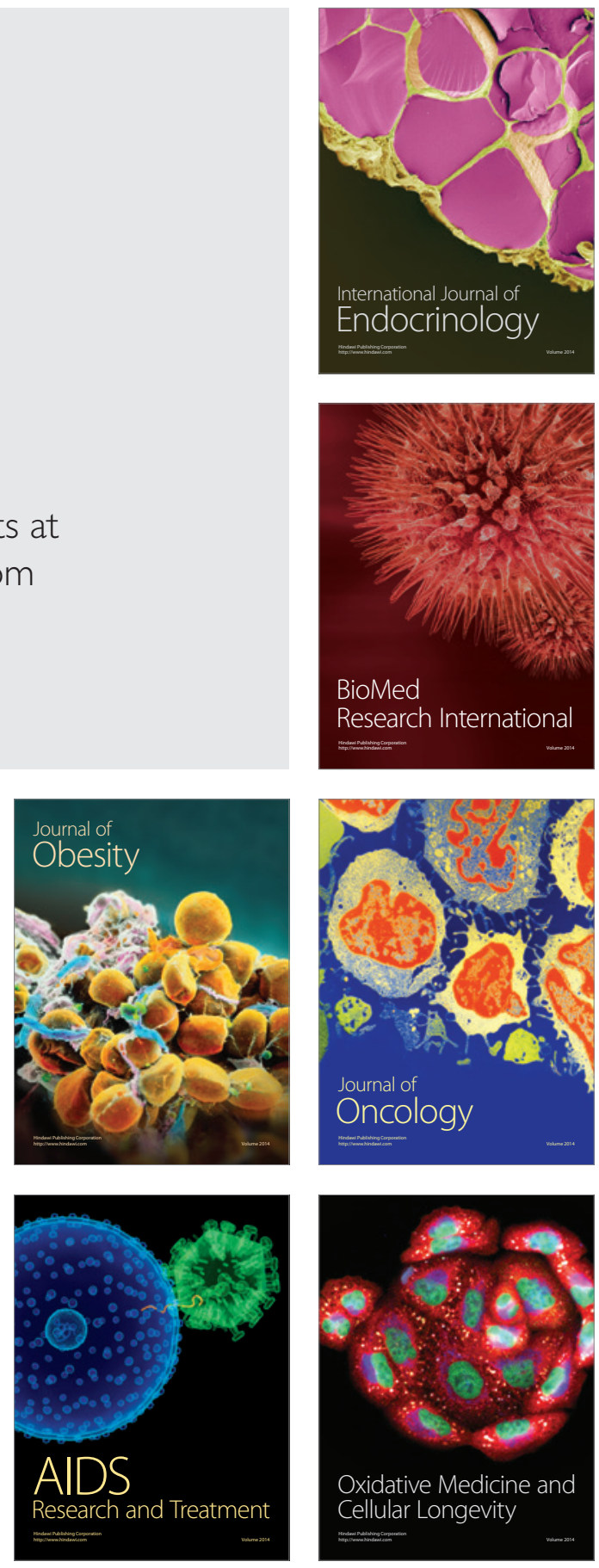